\title{
Cyclic Voltammetry of Aqueous Copper (II)- Pentamethyldiethylenetriamine Systems at Various pH Values.
}

\author{
Emmanuel J. Ukpong*, Inimfon A. Udoetok, Nyeneime W. Akpanudo. \\ Department of Chemistry, Faculty of Science, Akwa Ibom State University, Ikot Akpaden, Nigeria.
}

\begin{abstract}
The redox behaviour of Copper(II)-pentamethyldiethylenetriamine(pmdt) system has been studied in aqueous $0.2 \mathrm{M} \mathrm{NaClO}_{4} \cdot 6 \mathrm{H}_{2} \mathrm{O}$ supporting electrolyte at glassy carbon electrode(GCE) at various $\mathrm{pH}$ and pmdt concentration values by means of cyclic voltammetry. The cyclic voltammetric parameters are calculated. The first couple $\mathrm{Cu}^{2+/+}$ showed a diffusion controlled, quasi-reversible, one electron charge transfer at GCE. The intensities of both cathodic and anodic peak current are increased with increasing scan rate consistent with Randles-Sevcik equation. The cyclic voltammograms indicated the presence of more than one complex specie in solution followed by complicated anodic response except for 1:100 Cu(II)-pmdt system at pH11.04. A linear behaviour of peak current versus square root of scan rate indicated that the electrochemical processes are diffusion controlled for 1:100 Cu(II)-pmdt at $\mathrm{pH}$ 7.10.
\end{abstract}

Keywords: Cyclic Voltammetry, Copper (II) Complex, pentamethyldiethylenetriamine, aqueous medium, quasireversible, diffusion-controlled.

\section{I. $\quad$ 1.Introduction}

Copper is an important trace element for plants and animals (Gaudin,1967; Seigel,1974) and is involved in mixed ligand complex formation in a number of biological processes( Patel et al 2004; Bjerrum, $1941 ;$ ) . Also, the synthesis of low molecular weight copper (II) complexes mimicking the SOD activity has been challenging to bioinorganic chemists and for many years efforts have been made to obtain compounds with high catalytic activity (Patel, 2003). Pentamethyldiethylenetriamine (PMDT) is a tridentate nitrogen donor ligand with donor groups suitably placed for forming 5-membered chelate rings. Such tridentate ligands are known to form stable mononuclear and binuclear copper (II)complexes which have been a subject of extensive studies( Patel, 2004) . Copper complexes are commonly air and moisture stable, having informative and easy to obtain UV-vis and EPR spectroscopic signatures. The stereochemical flexibility of copper (II)complexes also means that they adopt a wider range of coordination geometries shown for transition metal ion( Hathaway, 1984).

$\mathrm{pH}$ is an important factor influencing complex formation and stability. Most chelating agents are unstable in low $\mathrm{pH}$ whereas at high $\mathrm{pH}$, metals tend to form insoluble hydroxides which are less accessible to chelating agent ( Flora \& Pachauri 2010). Electrochemical studies of $\mathrm{Cu}(\mathrm{II})$ reduction in various electrolytes in the acidic and basic $\mathrm{pH}$ range have been studied ( Shaikh et al 2011). In nitrate and perchlorate media the $\mathrm{Cu}(\mathrm{II})$ reduction was $\mathrm{pH}$ dependent (Anderson \& Shain 1976). In nitrate and chloride solution, copper reduction is complete in $\mathrm{pH}$ range $\mathrm{pH} 2<\mathrm{pH} 4.5$ ( Mecucci \& Scott).

Diethylenetriamines are highly caustic, soluble in ethyl alcohol, in water, and have almost the same physiological properties like ammonia ( Quattara \& Diaco 2006). Due probably to their high causticity, their electrochemical oxidation is not too much investigated.

Cyclic voltammetry offers several distinct advantages over some methods of analysis because of ease of and rapidity to work outside $\mathrm{pH}$ range of glass electrodes and to use non-protic media ( Quattara \& Diaco 2006). This in turn permits straight forward determination of kinetic parameters ( Munoz et al 1988). As cyclic voltammetry is the most effective and versatile technique in the diagnosis of complex electrode mechanism ( Shaikh, 2011), in the present study, this technique is employed to examine the electrochemical behaviour of $\mathrm{Cu}(\mathrm{II})$-pmdt system in aqueous $\mathrm{NaClO}_{4}$ medium under conditions of various $\mathrm{pH}$ and ligand concentrations.

\section{Materials and Method}

Analar grade copper perchlorate and sodium perchlorate were procured. Pentamethyldiethylenetriamine was obtained from Aldrich (USA). To adjust the $\mathrm{pH}$ of the solution, perchloric acid and sodium hydroxide (BDH) were used.The cyclic voltammetric data wre obtained with BAS model CVIB (Indiana, USA) cyclic voltammograph instrument having an electrochemical cell with a three electrode system. The working electrode was a glassy carbon electrode (GCE). Platinum wire was used as an auxiliary electrode, while a saturated calomel (SCE) as the reference electrode with $E^{\circ}=0.242 \mathrm{~V}$ vs NHE. The voltammograms were recorded on an $\mathrm{X}-\mathrm{Y}$ recorder. The $\mathrm{pH}$ of the working solutions were obtain with a digital 
pH meter Model MD21 after calibration using pH 4.00, 7.00, and10.00 commercial standard buffers. All the experiments were done in an inert atmosphere achieved by purging the cell solutions with nitrogen gas for about 20 minutes and maintained over the cell solution(s) during the recording of the voltammograms. The nitrogen gas was purified by bubbling through alkaline vanadous sulphate solution and passing through a calcium sulphate drying tube before bubbling the cell solution(s). The glassy carbon electrode (GCE), was polished with fine alumina powder on wet polishing cloth for about 5 minutes. The shiny black mirror like electrode surface was then thoroughly washed with double distilled water. Fresh solutions of copper(II)-pmdt complexes were prepared by mixing the appropriate quantities of metal ion and ligand solutions to obtain 1:1, 1:2, 1:10, and 1:100 molar ratios , $1 \mathrm{mMCu}\left(\mathrm{ClO}_{4}\right)_{2} \cdot 6 \mathrm{H}_{2} \mathrm{O}$. The $\mathrm{pH}$ of the solutions was adjusted by controlled addition or sodium hydroxide or perchloric acid solution as required. All experiments were carried out at $25^{\circ} \mathrm{C}$ and all solutions were prepared in double distilled water

\section{Results and Discussion}

The cyclic voltammetric study of 1:1 mM Cu(II)-pmdt system at $\mathrm{pH} 7.10,9.10$ and 10.20 was investigated at GCE within the potential windows of +0.60 to $-0.70 \mathrm{~V}$ at $25 \mathrm{mV} / \mathrm{s}$. Figure 1 is the cyclic voltammogram $(\mathrm{CV})$ at $\mathrm{pH} 7.10$. A cathodic sweep with an initial potential of $+0.30 \mathrm{~V}$ shows one small irreversible reduction peak, $\mathrm{c}_{1}^{\prime}$ at $-245 \mathrm{mV}$ and a quasi-reversible reduction peak, $\mathrm{c}_{1}$ at $-405 \mathrm{mV}$ which is followed by three oxidation peaks at $-300 \mathrm{mV}\left(\mathrm{a}_{1}\right),+185 \mathrm{mV}\left(\mathrm{a}_{1}^{\prime}\right)$ and $+455 \mathrm{mV}\left(\mathrm{a}_{1}^{\prime \prime}\right)$ in the reverse sweep. The peak potentials are slightly changed in the second cycle. The appearance of two reduction peaks $\mathrm{c}_{1}^{\prime /}$ and $\mathrm{c}_{1}$ clearly demonstrates the presence of more than one $\mathrm{Cu}$ (II)-complex species in solution at $\mathrm{pH} 7.10$. On increasing the scan rate to $100 \mathrm{mV} / \mathrm{s}$, the second oxidation peak $\mathrm{a}_{1}^{\prime}$ broadened and the third $\mathrm{a}_{1}^{\prime}$ disappeared. This clearly shows that EC mechanism (Nicholson \& Shain,1964; Becker et al 1982; Harmalker et al 1983; Pandeya et al 1994), is involved in the electrode process.

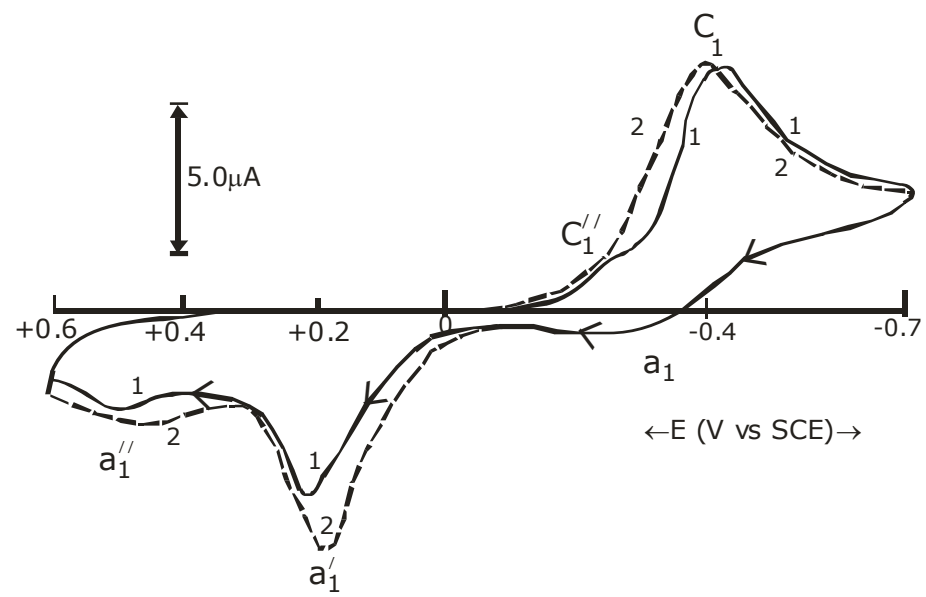

Figure 1: $\mathrm{CV}$ of $1: 1 \mathrm{Cu}(\mathrm{II})$ pmdt system, $1 \mathrm{mM} \mathrm{Cu}\left(\mathrm{ClO}_{4}\right)_{2}$ at $\mathrm{pH} 7.10$ and $25 \mathrm{mV} / \mathrm{s}$

At $\mathrm{pH}$ 9.10, the $\mathrm{CV}$ features differ from that at $\mathrm{pH} 7.10$ in that the peak current Ipa is smaller and it's potential has shifted towards negative direction at $\mathrm{pH} 9.10$. Also, a new cathodic peak $\mathrm{c}_{1}^{\prime}$ at $-210 \mathrm{mV}$ appeared in the second cycle which may be attributed to the reduction of electro-oxidised $\mathrm{Cu}(\mathrm{II})$ species to $\mathrm{Cu}(0)($ figure 2$)$.

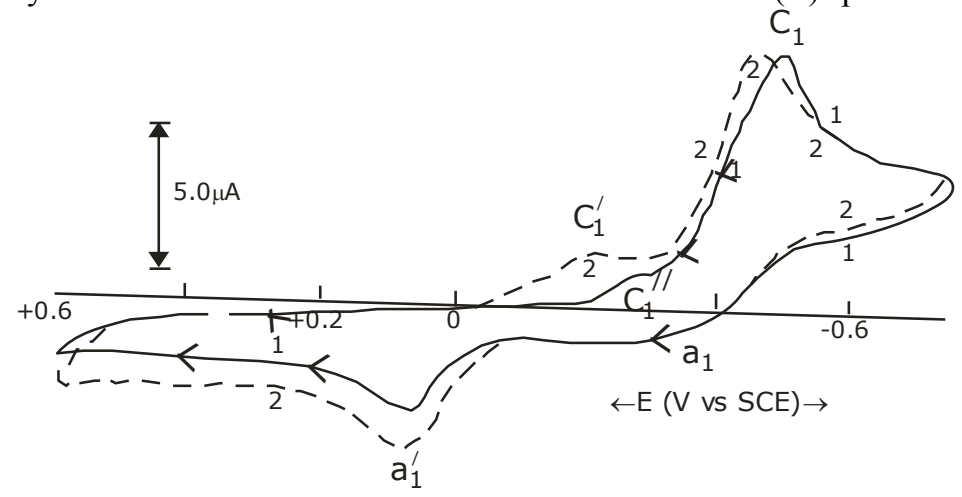

Figure 2: $\mathrm{CV}$ of 1:1 $\mathrm{Cu}$ (II) pmdt system, $1 \mathrm{mM} \mathrm{Cu}\left(\mathrm{ClO}_{4}\right)_{2}$ at $\mathrm{pH} 9.10$ and $25 \mathrm{mV} / \mathrm{s}$

At $\mathrm{pH} 10.20$, the $\mathrm{CV}$ features are similar to that at $\mathrm{pH} 9.10$ except that a very small new oxidation peak $\mathrm{a}_{2}$ at $250 \mathrm{mV}$ assigned to electro-oxidation of copper(0) into copper(I) species appeared. Also, the oxidation peak $\mathrm{a}_{1}^{\prime}$ 
further shifted cathodically. When the potential window was increased to $-1.05 \mathrm{~V}$, an irreversible additional cathodic peak, $\mathrm{c}_{2}$ corresponding to $\mathrm{Cu}^{+/ 0}$ redox change appeared. However, in the reverse scan, the oxidation peak, $\mathrm{a}_{1}^{\prime}$ appeared as stripping peak followed by another oxidation peak $\mathrm{a}_{1}^{\prime \prime}$ at $\mathrm{pH}$ 7.10. At $\mathrm{pH}$ 9.10, a rather more complicated oxidation processes $\mathrm{a}_{1}, \mathrm{a}_{1}^{\prime /}$ and $\mathrm{a}_{1}^{\prime \prime \prime}$ appeared. The $\mathrm{CV}$ features at 10.20 differ from that at pH 9.10 with respect to oxidation processes occurring at $a_{2}, a_{1}^{\prime}$ and $a_{1}^{\prime \prime}$. The broad oxidation peak $a_{2}$ is absent while $\mathrm{a}_{1}^{\prime}$ is very large at $\mathrm{pH} 9.10$.

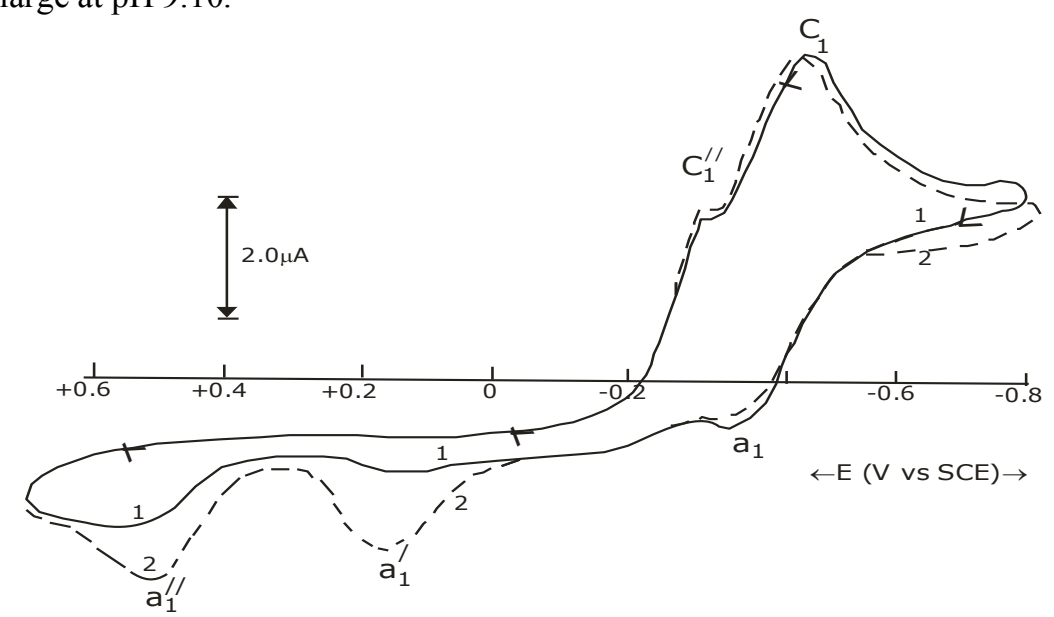

Figure 3: $\mathrm{CV}$ of 1:2 $\mathrm{Cu}$ (II) pmdt system, $1 \mathrm{mM} \mathrm{Cu}\left(\mathrm{ClO}_{4}\right)_{2}$ at $\mathrm{pH} 7.10$ and $10 \mathrm{mV} / \mathrm{s}$

For $1: 2 \mathrm{mM} \mathrm{Cu}(\mathrm{II})$-pmdt system , at $\mathrm{pH} 7.10$, the $\mathrm{CV}$ (figure 3) features scanned at $10 \mathrm{mV} / \mathrm{s}$ showed two reduction peaks $\mathrm{c}_{1}^{\prime \prime}$ and $\mathrm{c}_{1}$ and three anodic peaks $\mathrm{a}_{1}$,(small), $\mathrm{a}_{1}^{\prime}$ (broad) and $\mathrm{a}_{1}^{\prime}$ (broad). The cathodic peak current Ipc $_{1}^{\prime}$ is larger as compared to $1: 1 \mathrm{mM} \mathrm{Cu}(\mathrm{II})$-pmdt system at $\mathrm{pH} 7.10$. This indicates that both the species are prominent in 1:2 ratio at this $\mathrm{pH}$. The oxidation peaks $\mathrm{a}_{1}^{\prime}$ and $\mathrm{a}_{1}^{\prime \prime}$ are absent at $\mathrm{v} \geq 100 \mathrm{mV} / \mathrm{s}$ (figure 4). This clearly demonstrates that EC mechanism(Nicholson \& Shain,1964; Becker et al 1982; Harmalker et al 1983; Pandeya et al 1994), is involved in the electrode process. Furthermore, an increase in pH to 9.10 results into decrease in the peak current $\mathrm{Ipc}_{1}^{\prime}$.

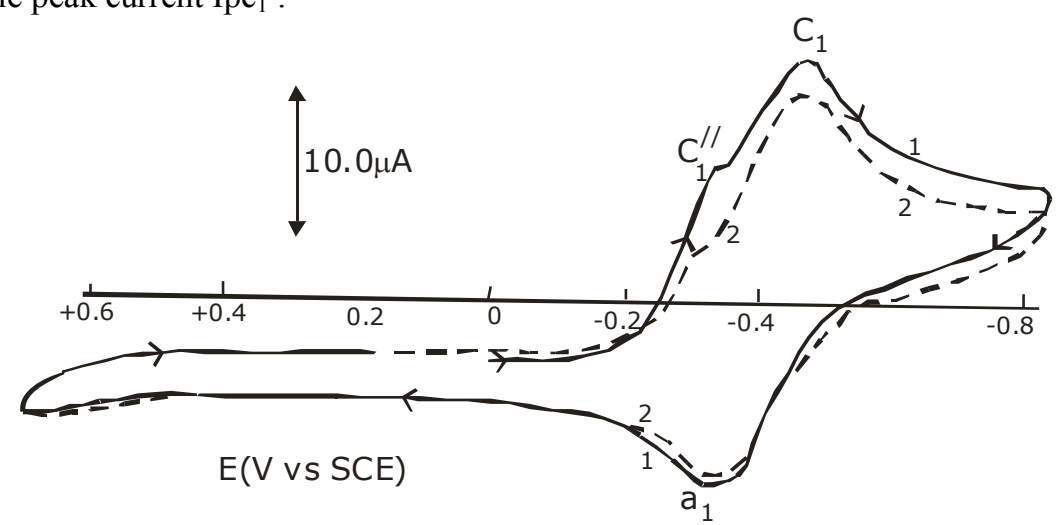

Figure 4: $\mathrm{CV}$ of $1: 2 \mathrm{Cu}$ (II) pmdt system, $1 \mathrm{mM} \mathrm{Cu}\left(\mathrm{ClO}_{4}\right)_{2}$ at $\mathrm{pH} 7.10$ and $100 \mathrm{mV} / \mathrm{s}$

Figure 5 is the $\mathrm{CV}$ for $1: 10 \mathrm{mM} \mathrm{Cu}(\mathrm{II})$-pmdt system at $\mathrm{pH}$ 7.10. A comparison of figure 5 with figure 3 shows that the $\mathrm{CV}$ features for 1:10 and 1:2 $\mathrm{Cu}(\mathrm{II})$-pmdt systems are similar at $\mathrm{pH} 7.10$ except that the second anodic peak $\mathrm{a}_{1}^{\prime}$ is absent in the first cycle in the case of $1: 10 \mathrm{mMCu}(\mathrm{II})$-pmdt system. However, the oxidation peak, $\mathrm{a}_{1}^{\prime}$ appears and the magnitudes of the anodic peak currents Ipa ${ }_{1}, \mathrm{Ipa}_{1}^{\prime}$ and Ipa ${ }_{1}^{\prime \prime}$ are increased in the second cycle for 1:10 $\mathrm{Cu}(\mathrm{II})$-pmdt system. The $\mathrm{CV}$ features for 1:10 $\mathrm{Cu}(\mathrm{II})$-pmdt system at $\mathrm{pH} 9.10$ and 11.04 are similar to that at $\mathrm{pH}$ 7.10. Similarly, the $\mathrm{CV}$ features for $1: 100 \mathrm{Cu}(\mathrm{II})$-pmdt system are similar to that for 1:10 molar ratio at $\mathrm{pH} 7.10$ ( figure 5), except that only a very small oxidation peak $\mathrm{a}_{1}^{\prime \prime}$ appeared in the 1:100 molar ratio. At $\mathrm{pH}$ 11.04, a well defined quasi -reversible redox couple $\mathrm{c}_{1} / \mathrm{a}_{1}$ appeared in the case of 1:100 $\mathrm{Cu}(\mathrm{II})$-pmdt system. 


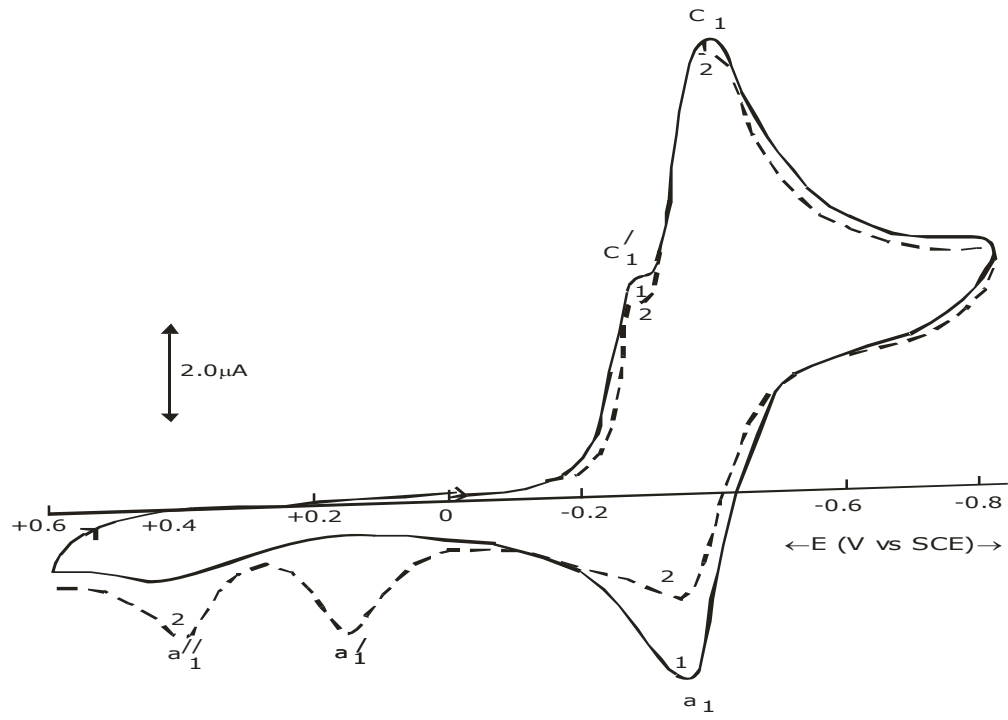

Figure 5: $\mathrm{CV}$ of 1:10 $\mathrm{Cu}$ (II) pmdt system, $1 \mathrm{mM} \mathrm{Cu}\left(\mathrm{ClO}_{4}\right)_{2}$ at $\mathrm{pH} 7.10$ and $25 \mathrm{mV} / \mathrm{s}$

The effect of scan rate on the electrochemical response of $\mathrm{Cu}(\mathrm{II})$-pmdt system for the first couple $\mathrm{Cu}^{+/++}$was examined and the best fit was found for 1:100Cu(II)pmdt at $\mathrm{pH} 7.10$ between scan rate 25 to $250 \mathrm{mV} / \mathrm{s}$.

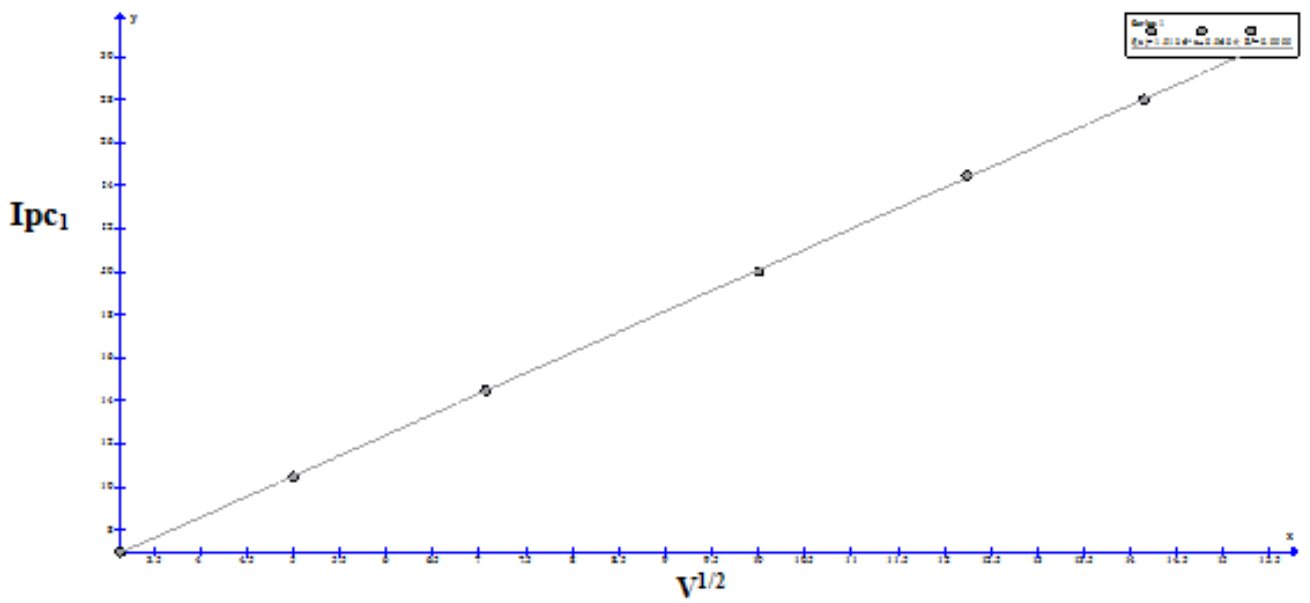

Figure 6: Dependence of $\mathrm{Ipc}_{1}$ with $\mathrm{V}^{1 / 2}$ for $1: 100 \mathrm{Copper}$ (II) pmdt system in $0.2 \mathrm{NaClO}_{4}$ at $\mathrm{pH} 7.10$

The cathodic $\left(\mathrm{Epc}_{1}\right)$ and anodic $\left(\mathrm{Epa}_{1}\right)$ peak potentials, peak currents $\left(\mathrm{Ip}_{1}\right)$ and peak current ratio $\left(\mathrm{Ipa}_{1} / \mathrm{Ipc}_{1}\right)$ and peak separation $\triangle \mathrm{Ep}$ are gathered in table 1 . With increasing scan rate, both cathodic and anodic peak current increases and the cathodic peak potentials have shifted towards negative values while anodic peak potentials move towards more positive values. These observation suggest that the electrode process is diffusion controlled at GCE( Shaikh et al 2011; Nicholson and Shain 1964 ).In figure 6, it is apparent the peak current for $1: 100 \mathrm{mMCu}(\mathrm{II})$ pmdt system has a linear relation with square root of scan rate with a correlation coefficient of 0.9999 and intercept of +0.9604 . Also the Slope of $\log \mathrm{Ipc}_{1}$ vs $\log \mathrm{v}$ (figure7) was 0.46 which is in good agreement with the theoretical expected value of 0.50 for purely diffusion controlled process ( Shaikh et al 2011; Deepa, et al 2012). This indicate that diffusion controlled conditions dominate the mass transfer mechanisms of the monomer to the electrode surface( Shaikh et al 2011).

Table 1 Peak currents and peak potentials at different scan rate of 1:100 $\mathrm{Cu}(\mathrm{II}-)$ pmdt system at pH 7.10

\begin{tabular}{|c|c|c|c|c|c|c|}
\hline Scan rate $\mathrm{mV} / \mathrm{s}$ & $\mathrm{Epc}_{1} / \mathrm{mV}$ & $\mathrm{Epa}_{1} / \mathrm{mV}$ & $\mathrm{Ipc}_{1} / \boldsymbol{\mu A}$ & $\mathrm{Ipa}_{1} / \boldsymbol{\mu A}$ & $\mathrm{Ipa}_{1} / \mathrm{Ipc}_{1}$ & $\Delta \mathbf{E p} / \mathbf{m V}$ \\
\hline 10 & -415 & -350 & 7.0 & 4.5 & 0.64 & 75 \\
\hline 25 & -415 & -340 & 10.5 & 6.5 & 0.61 & 80 \\
\hline 50 & -420 & -335 & 14.5 & 9.0 & 0.62 & 80 \\
\hline 100 & -430 & -330 & 20.5 & 12.0 & 0.60 & 90 \\
\hline 150 & -435 & -330 & 24.5 & 14.5 & 0.59 & 95 \\
\hline 200 & -440 & -330 & 28.0 & 17.0 & 0.60 & 100 \\
\hline 250 & -440 & -320 & 31.2 & 18.5 & 0.59 & 110 \\
\hline
\end{tabular}




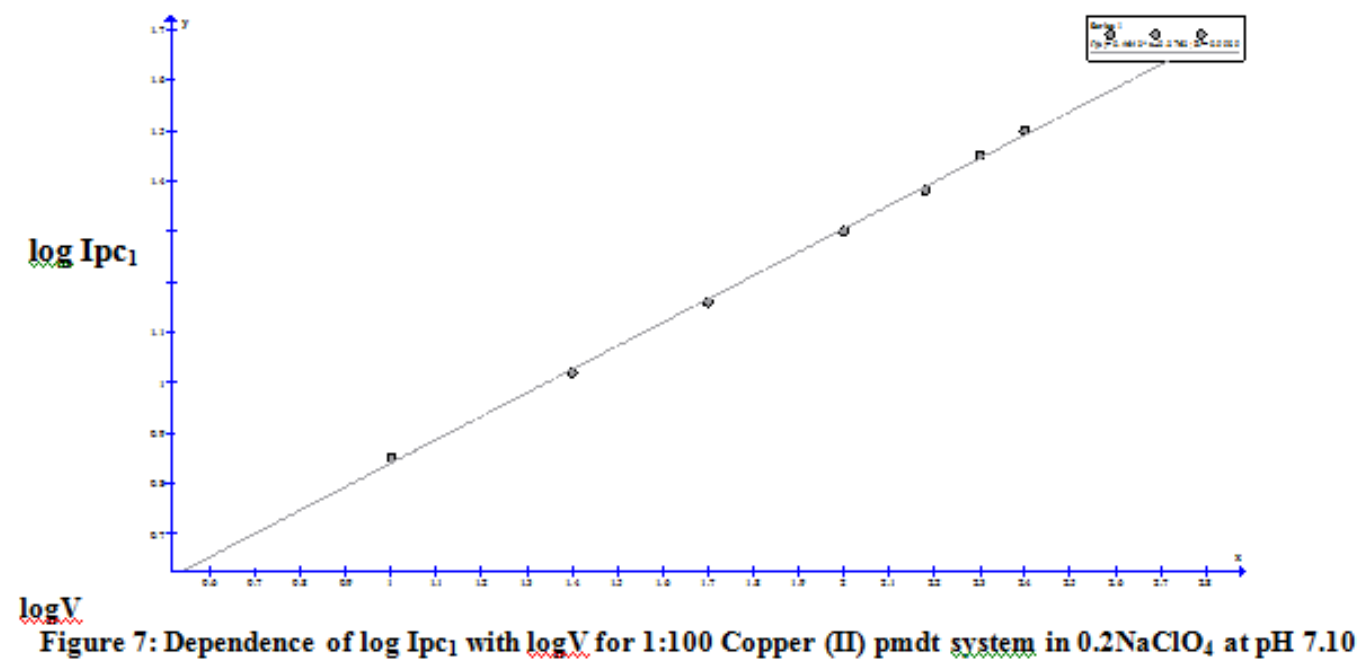

The ratio of the oxidation peak current to it's reduction counterpart $\mathrm{Ipa}_{1} / \mathrm{Ipc}_{1}$, is $0.64-0.59$ which remains approximately constant with increasing scan rate. Also, the $\Delta \mathrm{Ep}$ is between 75 to 110 . It is increased with the variation of scan rate (table 1). These suggest that the redox process is quasi-reversible rather than reversible ( Shaikh et al 2011). The analysis of the electrode process for $1: 10 \mathrm{mM} \mathrm{Cu(II)-pmdt} \mathrm{system} \mathrm{shows} \mathrm{that} \mathrm{at} \mathrm{pH}$ 7.10 , a larger peak separation, $\Delta E \mathrm{Ep}$ coupled with a systematic increase of $\Delta \mathrm{Ep}$ with scan rate (110-165) occurred. With the increase of scan rate, negative shift in $\mathrm{Epc}_{1}$ and a corresponding positive shift in Epa $\mathrm{A}_{1}$ were found. These behaviours indicate kinetic limitations in charge transfer (Shaikh et al 2011) with the redox system at this $\mathrm{pH}$ and for 1:10 molar ratio.

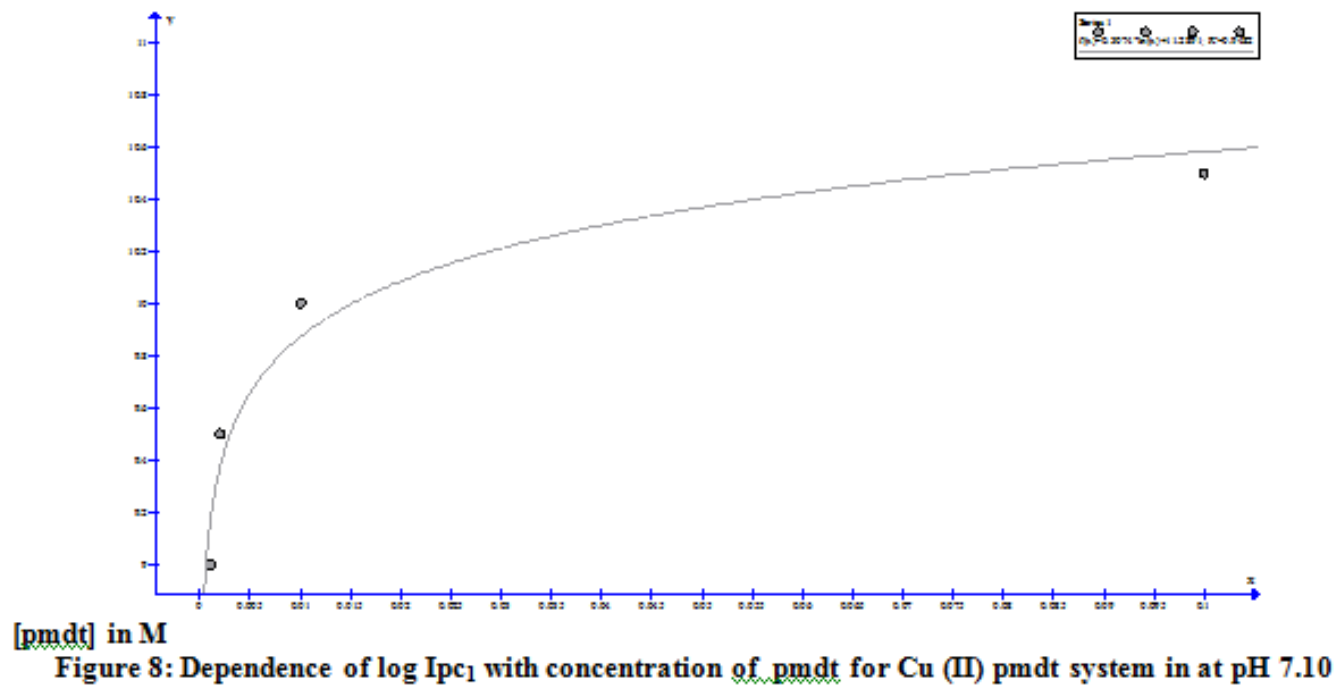

The plot of Ipc $\mathrm{I}_{1}$ versus concentration of pmdt in the range of $.001 \times 10^{-3}$ to $.1 \times 10^{-3} \mathrm{M}$ showed that at $\mathrm{pH} 7.10 \mathrm{Ipc}_{1}$ increases with increase in concentration of pmdt (figure 8) while the opposite was observed at $\mathrm{pH} 9.10$ (figure 9).This indicate that probably, at $\mathrm{pH} 7.10$, the complex specie in solution are stabilized. However at $\mathrm{pH} 9.10$, probably destabilization of complex specie due to the steric effect of bulky pmdt is pronounced contrary to expectation since at high $\mathrm{pH}, \mathrm{OH}^{-}$ions are expected to participate in formation of stable $\mathrm{Cu}(\mathrm{II})$ complex specie such as $\left[\mathrm{Cu}(\mathrm{pmdt})\left(\mathrm{OH}_{2}\right)\right]^{2+}$ or $\left[\mathrm{Cu}(\mathrm{pmdt})(\mathrm{OH})_{2}\right]\left(\mathrm{ClO}_{4}\right)_{2}$ ( Patel, et al 2004) in solution. 


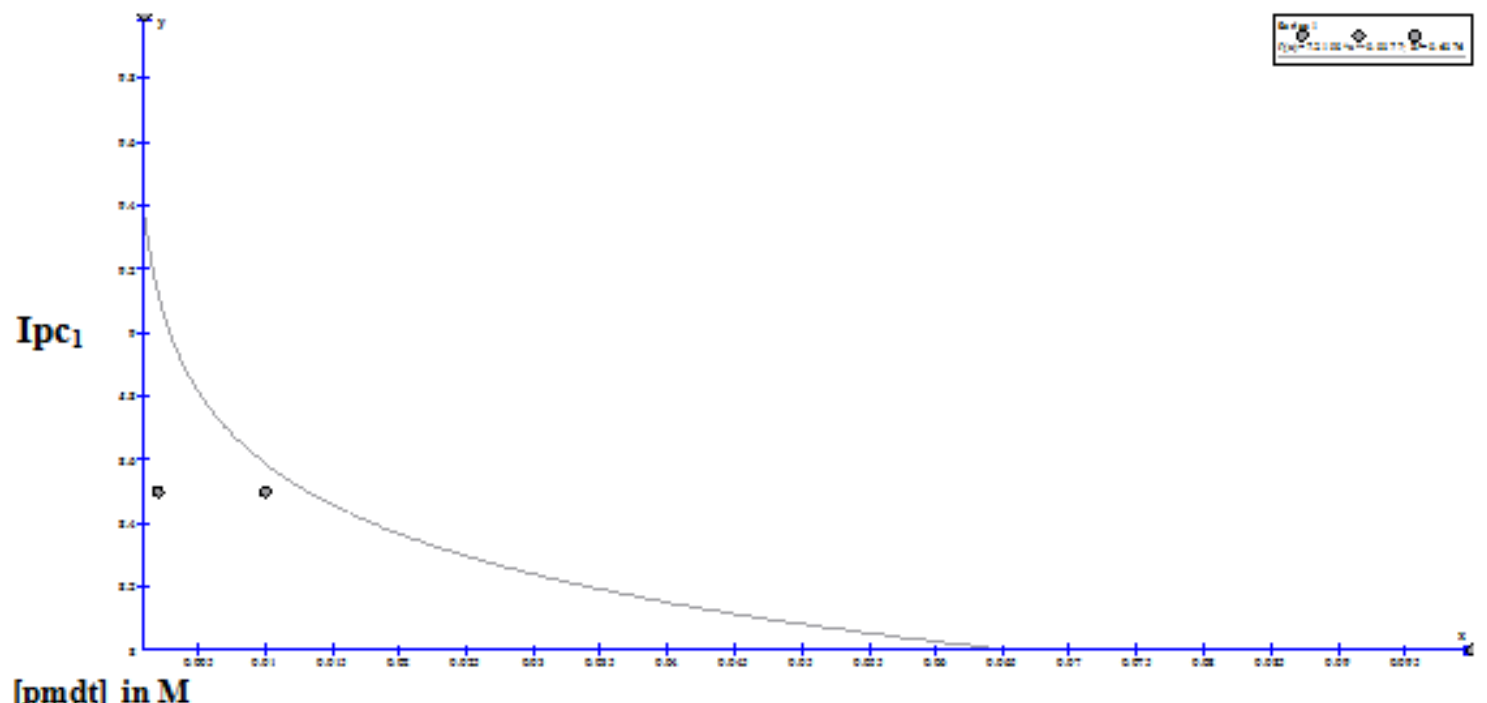

Figure 8: Dependence of $\log \mathrm{Ipc}_{1}$ with concentration of $\mathrm{pmdt}$ for $\mathrm{Cu}$ (II) pmdt system in at $\mathrm{pH} 7.10$

\section{Conclusions}

The results obtained from cyclic voltammetry indicate unambiguously that under the experimental conditions there are more than one $\mathrm{Cu}$ (II) complexe specie in solution except in 1: $100 \mathrm{Cu}$ (II)-pmdt system at $\mathrm{pH} 11.04$ where a well defined c1/a1 redox couple is obtained. The appearance of complicated anodic peaks is an interesting observation which needs characterisation using additional technique. The result obtained confirms that the electrode process is best fit for $1: 100 \mathrm{mM} \mathrm{Cu}(\mathrm{II}) \mathrm{pmdt}$ at $\mathrm{pH} 7.10$.

\section{References}

[1]. Anderson, J. L., \& Shain, L., (1976). Cyclic Voltammetric Studies of the pH dependence of Copper (II) reduction in Acidic Aqueous Nitrate and Per chlorate solutions. Anal. Chem. 48(9), 1274-1282.

[2]. Bjerrum, J. (!941).metal Amine formation in Aqeous Solution, P. Haase and sons, Coppenhagen, p. 298.

[3]. Becker, J., Brockway, D., Murray, K. S., Newman, P \& Toftlund, T., (1982). Electron Spin resonance \& Electrochemical study of Thiohydroxamate \& 1-Phenyl-3-imino-2(1H)- Pyridinethione complexes of Copper (II). Inorg Chem. 21(5), 1791-1798.

[4]. Deepa, M. B., Mamatha, G. P., Shergara, B. S. \& Arthobanaik, Y. (2012). Electrochemical Studies of Ceftriaxone on Eriochrome Black- T Polymer Film Modified Glassy Carbon Electrode .Int. J. Res. Chem. And Environ. 2(1), 153-159.

[5]. Flora, S. J. S., \& Fellman, J. H. (1967). The Biolosynthesis of DOPA in Albino Skin. Biophys. Acta. 141, 64-70

[6]. Hathaway, B. J. (1984). Structure and Bonding ( Berlin), 57, p. 55.

[7]. Harmalker, S., Jones S. E. \& Sawyer, D. T.(1983). Electrochemical and Spectrocopic Studies of 3, 5 - di- tert- butylcatecholato and 3, 5 di-tert- butyl-o- Semiquinato Complexes of Copper(II). Inorg. Chem. 22, 2790-2794.

[8]. Mecucci, A., \& Scott, K. Electrochemical Society Proceedings Vol. 2001-2023.

[9]. Munoz, E., Avilla, J.L. Camacho, L., Cosano, J. E., Garcia Blanco, J. (1988). Study of the Adsorption \& Surface reduction of Cefazolin by Cyclic Voltammetry. J. Electro. Anal. Chem. 257-281.

[10]. Nicholson, R. S. \& Shain, I.(1964). Theory of Stationary Polarography: Single Scan \& Cyclic methods Applied to reversible \& Kinetic Systems . Anal. Chem. 36, 706-723.

[11]. Patel, R. N., Singh, N., Shukla, K. K., Chauhan, U. K., Chakraborty, S. (2004). X- ray, Spectral \& Biological ( antimicrobial \& superoxide dismutase ) Studies of Oxalato Bridged $\mathrm{Cu}(\mathrm{II})$ - Ni(II) \& $\mathrm{Cu}(\mathrm{II})-\mathrm{Zn}(\mathrm{II})$ Complexes with Pentamethyldiethylenetriamine as capping ligand. Journal of Inorganic Biochemistry 98(2), 231-237.

[12]. Patel, R. N. (2003). Magnetic, EPR \& SOD Studies of Some $\mathrm{Cu}^{\mathrm{II}}-\mathrm{Cu}^{\mathrm{II}}, \mathrm{Cu}^{\mathrm{II}}-\mathrm{Ni}{ }^{\mathrm{II}} \& \mathrm{Cu}^{\mathrm{II}}-\mathrm{Zn}^{\mathrm{II}}$ imidazolate Bridged Complexes. Spectrochimica, Acta, Part A 59, 713-721.

[13]. Pandeya, K. B., Khare D., Prasad, J. \& Srivastava, K. (1994). Unusual Cyclic Voltammetric Behavior of Oxovanadium (IV) Chelates of Some Schiff Bases. Microchem. Journal 50, 136-140.

[14]. Quattara, L., Diaco. T., Bokra, Y. (2006). Influence of water on the Anodic Mechanis of Diethylenetriaamine on Platinum Electrode. Bull. Of Chem. Soc. Ethiopia 20(20), 269-277. 